\title{
Patologia oczodołu w materiale Kliniki Otorynolaryngologii Klinicznego Szpitala Wojewódzkiego Nr 1 w Rzeszowie w latach 2000-2013
}

\section{Orbital pathology in material of Otolaryngology Clinic of the Regional Specialist Hospital No 1 in Rzeszów between 2000-2013}

\author{
Katarzyna Augustyn ${ }^{1}$, Sławomir Łukasik ${ }^{1}$, Grażyna Mielnik-Niedzielska² \\ ${ }^{1}$ Kliniczny Szpital Wojewódzki Nr 1 w Rzeszowie, Klinika Otorynolaryngologii \\ ${ }^{2}$ Uniwersytecki Szpital Kliniczny w Lublinie, Klinika Laryngologii Dziecięcej, Foniartii i Audiologii \\ Adres autora: Katarzyna Augustyn, Kliniczny Szpital Wojewódzki Nr 1 w Rzeszowie, Klinika \\ Otorynolaryngologii, ul. Szopena 2, 35-055 Rzeszów, e-mail: kaau@esculap.pl
}

\section{Streszczenie}

Wprowadzenie: Schorzenia oczodołu ze względu na swoją różnorodność wymagają współpracy specjalistów z różnych dziedzin medycyny. Wśród schorzeń oczodołu wymienić należy urazy, stany zapalne, nowotwory, objawy chorób ogólnoustrojowych. Wszystkie schorzenia mogą stanowić niebezpieczeństwo dla narządu wzroku, a nawet zagrożenie życia.

Cel pracy: Celem pracy była analiza częstotliwości występowania schorzeń oczodołu w grupie pacjentów hospitalizowanych w Klinice Otolaryngologii Klinicznego Szpitala Wojewódzkiego Nr 1 w Rzeszowie.

Materiał i metoda: Badaniem objęto grupę 35 chorych hospitalizowanych z powodu schorzeń oczodołu.

Wyniki: W badanej grupie chorych $62,8 \%$ to chorzy leczeni z powodu powikłań oczodołowych w przebiegu zapalenia zatok. Osoby hospitalizowane z powodu podejrzenia guza oczodołu stanowiły $14,2 \%$. Pozostali pacjenci to grupa chorych, u których schorzenia oczodołu były poprzedzone inną patologią niż zapalenie zatok.

Wnioski: Schorzenia oczodołu stanowią heterogenną grupę schorzeń. Najliczniejsza grupa to chorzy z powikłaniami zatokowymi.

Słowa kluczowe: guzy oczodołu • ropień oczodołu • zapalenie tkanki łącznej

Abstract

Introduction: Orbital disorders have different orgins and require interdysciplinary diagnosis. Some of the orbital disorders are: orbital cellulitis, tumours, orbital trauma and different symptoms of systemic disorders. All of these can pose threat to the eyes, or even be fatal.

Aim: The aim of the study was to analyse the occurrence of different orbital disorders in patients treated in the Otolaryngology Clinic.

Material and methods: The examination includes case studies of 35 in-patients with orbital pathologies.

Results: In the examined group, $62.8 \%$ were patients treated for post-sinusitis complications, whereas $14.2 \%$ of the patients were hospitalised because of the suspected orbital tumour. The remaining patients were treated for the orbital pathologies preceded by disorders other than sinusitis.

Conclusions: Orbital pathologies are heterogeneous group of disorders. The greatest number of patients suffered from postsinusitis complications. Other pathologies weren't as frequent.

Key words: orbital tumours • orbital abscess • orbital cellulitis 


\section{Wstęp}

Oczodół to struktura anatomiczna, gdzie krzyżują się pola zainteresowań różnych specjalności medycznych. Mogą być tam zlokalizowane zmiany o różnej etiologii, a ich objawy chorobowe są podobne. Objawy kliniczne mogą wystąpić pod postacią kłucia, pieczenia, łzawienia, podwójnego widzenia, upośledzenia ostrości wzroku aż do ślepoty, ograniczenia pola widzenia, wytrzeszczu, bólu, zaburzenia ruchomości gałki ocznej [1-4]. Szybkość narastania objawów jest cenną wskazówką diagnostyczną. Choroba może mieć przebieg ostry - objawy pojawiają się w ciągu kilku minut i sugerują krwawienie. Narastanie objawów w ciągu dni, tygodni jest charakterystyczne dla niespecyficznych procesów zapalnych, niektórych nowotworów (np. mięsak z komórek mięśni prążkowanych, przerzuty do oczodołu, ostra białaczka), specyficznych procesów zapalnych np. sarkoidozy. Wielomiesięczny lub kilkuletni wywiad jest charakterystyczny dla guzów łagodnych różnego pochodzenia. Towarzysząca infekcja górnych dróg oddechowych sugeruje etiologię zapalną [2-5].

Metodami diagnostycznymi szeroko stosowanymi w celu określenia charakteru zmiany są: USG oczodołu, tomografia komputerowa oraz rezonans magnetyczny. USG oczodołów to nieinwazyjna metoda pozwalająca wykryć zmiany w obrębie gałki ocznej. USG w prezentacji A ocenia struktury znajdujące się wzdłuż jednej prostej, w prezentacji B - struktury leżące w jednej płaszczyźnie. Standardowa prezentacja A w połączeniu z prezentacją B i techniką dopplerowską może zostać wykorzystana do badania przepływów w naczyniach gałki ocznej. Badanie USG jest przydatne nie tylko w diagnostyce zmian w obrębie oczodołów, lecz także w monitorowaniu procesów patologicznych ze względu na swoją dużą dostępność i nieinwazyjność [6-8]. Rutynowe zdjęcia przeglądowe czaszki tylno-przednie i boczne, zdjęcie zatok przynosowych, kanałów wzrokowych (zdjęcie w projekcji Rhese) są wypierane przez tomografię komputerową oraz rezonans magnetyczny [7]. Badanie tomografii komputerowej pozwala uwidocznić struktury kostne oczodołu, mięśnie zewnątrzgałkowe, gałkę oczną, pozagałkowe ciało tłuszczowe oczodołu. Badanie TK jest przydatne w wykrywaniu i lokalizacji ciał obcych oraz zmian pourazowych $[7,9]$. Badanie rezonansu magnetycznego umożliwia obrazowanie oczodołu w trzech różnych płaszczyznach bez narażenia chorego na działanie szkodliwego promieniowania rentgenowskiego. MR jest niezwykle przydatny w ocenie zmian zapalnych wewnątrz- i zewnątrzgałkowych guzów naciekających nerw wzrokowy i mięśnie pozagałkowe oraz zmian patologicznych skrzyżowania nerwów wzrokowych [7]. Badania angiograficzne i wenograficzne naczyń oczodołu mogą być wykorzystane do oceny zmian naczyniowych lub żylaków oczodołu [7].

W celu weryfikacji histopatologicznej zmian oczodołu można wykonać biopsję aspiracyjną lub biopsję otwartą oczodołu. Stwierdzenie w aspiracie komórek nowotworowych ma znaczenie diagnostyczne, natomiast ujemny wynik nie wyklucza procesu nowotworowego. Dlatego należy traktować biopsję jako badanie wstępne, nie zawsze mogące zastąpić biopsję otwartą [10]. 75\% wszystkich zakażeń bakteryjnych oczodołu jest następstwem zapalenia zatok przynosowych. W większości przypadków jest to powikłanie zapalenia zatok sitowych. Problem powikłań
Tabela 1. Leczenie powikłań oczodołowych zapalenia zatok

Table 1. Treatment of complication maxillary sinusitis

\begin{tabular}{ll}
\hline Leczenie zachowawcze & 5 chorych \\
\hline $\begin{array}{l}\text { Operacja zatok, orbitotomia, ewakuacja } \\
\text { ropnia oczodołu }\end{array}$ & 11 chorych \\
\hline $\begin{array}{l}\text { Rynoskopia, założenie sinu-jet do } \\
\text { zatok szczękowych objętych procesem } \\
\text { zapalnym }\end{array}$ & 2 chorych \\
\hline $\begin{array}{l}\text { Orbitotomia z ewakuacją ropnia } \\
\text { oczodołu }\end{array}$ & 4 chorych \\
\hline
\end{tabular}

oczodołowych w przebiegu zapalenia zatok dotyczy głównie dzieci, w 50\% poniżej 6 roku życia [11]. Wśród czynników wpływających na powstanie powikłań należy wymienić narastającą oporność bakterii na antybiotyki, stale rosnącą grupę chorych z upośledzoną odpornością [11].

Innymi zmianami patologicznymi są pseudoguzy oczodołu określane też jako idiopatyczne zmiany zapalne tkanek oczodołu. Częstość ich występowania w wieku dziecięcym to około $8,5 \%$, w wieku dorosłym do $18 \%[12,16]$.

Zmiany w oczodole mogą pojawić się w wyniku chorób ogólnoustrojowych takich jak: sarkoidoza, gruźlica, ziarniniak Wegenera, zespół Sjögrena, zaburzenia endokrynologiczne, chłoniak [12-15].

Oczodół to również miejsce rozwoju guzów pierwotnych, wtórnych pochodzących z narządów sąsiednich oraz guzów przerzutowych $[12,16]$. Pierwotne guzy oczodołu stanowią około $0,4 \%$ wszystkich nowotworów występujących u człowieka [12], z czego15-25\% występuje u dzieci[16]. 2-8\% guzów oczodołu jest spowodowanych przerzutami, najczęściej raka gruczołowego płuca i sutka [17].

\section{Materiał i metoda}

Przeprowadzono retrospektywną analizę dokumentacji medycznej chorych hospitalizowanych w Klinice Otorynolaryngologii Klinicznego Szpitala Wojewódzkiego Nr 1 w Rzeszowie w latach $2000-2013$ z powodu patologii oczodołu.

W grupie badanej było 35 osób. Wśród chorych było 7 mężczyzn (20\%) w wieku od 22 do 75 lat, 6 kobiet (17\%) w wieku od 32 do 74 lat, 22 dzieci (62\%), 17 chłopców i 5 dziewczynek w wieku od 2 do 18 lat. Średnia wieku chorych wynosiła 25,5 roku. U wszystkich osób wykonano badanie laryngologiczne, okulistyczne oraz tomografię komputerową zatok i oczodołów.

\section{Wyniki}

Najliczniejszą grupę stanowili chorzy hospitalizowani z powodu powikłań oczodołowych w przebiegu zapalenia zatok - 22 osoby $(62,8 \%)$.Wśród tych chorych większość stanowiły dzieci.

Pięciu chorych było leczonych zachowawczo z dobrym skutkiem. U pozostałych 17 chorych zastosowano leczenie 
Tabela 2. Pozostali chorzy hospitalizowani z powodu patologii oczodołu innej niż powikłania zatokopochodne Table 2. Other patients treated of orbital pathology without complication of maxillary sinusitis

\begin{tabular}{|c|c|c|}
\hline 2 chorych & $\begin{array}{l}\text { Ropień oczodołu poprzedzony czyrakiem wewnętrznego kąta } \\
\text { oka }\end{array}$ & Orbitotomia, ewakuacja ropnia \\
\hline 1 chory & $\begin{array}{l}\text { Zapalenie tkanek miękkich oczodołu poprzedzone mnogimi } \\
\text { czyrakami skrzydełka nosa }\end{array}$ & Leczenie operacyjne \\
\hline 1 chory & $\begin{array}{l}\text { Zapalenie tkanek miękkich oczodołu poprzedzone urazem głowy } \\
\text { ze złamaniem ściany oczodołu }\end{array}$ & Lecenie zachowawcze \\
\hline 1 chory & Ropowica oczodołu & Lecenie operacyjne \\
\hline 1 chory & Krwiak oczodołu & Ewakuacja krwiaka \\
\hline 1 chory & Wytrzeszcz jednostronny w przebiegu nadczynności tarczycy & Diagnostyka \\
\hline 5 chorych & Podejrzenie guza oczodołu & Usunięcie guza \\
\hline
\end{tabular}

Tabela 3. Wyniki badań histopatologicznych

Table 3. The results of histopathology

\begin{tabular}{cl}
\hline Liczba chorych & Wynik badania histopatologicznego \\
\hline 1 chory & Przewlekły stan zapalny \\
\hline 2 chory & $\begin{array}{l}\text { Przewlekłe zmiany zapalne gruczołu } \\
\text { łzowego }\end{array}$ \\
\hline 2 chorych & Chłoniak złośliwy \\
\hline
\end{tabular}

operacyjne. W tabeli 1. przedstawiono zastosowane leczenie $\mathrm{u}$ chorych z powikłaniami oczodołowymi w przebiegu zapalenia zatok. Kolejną grupę stanowili chorzy, u których schorzenia oczodołu nie były związane $\mathrm{z}$ patologią zatok. Do tej grupy zostali zaliczeni chorzy ze zmianami zapalnymi tkanek oczodołu, ropniem oczodołu w przebiegu czyraka skrzydełka nosa, czyraka kąta wewnętrznego oka, urazu oczodołu oraz chorzy z podejrzeniem guza oczodołu. U większości zastosowano leczenie operacyjne. Wyniki przedstawia tabela 2 .

Wyniki badania histopatologicznego materiału pobranego w czasie operacji pozwoliły na rozpoznanie przewlekłego stanu zapalnego tkanek oczodołu i gruczołu łzowego, chłoniaka złośliwego. Wyniki badań histopatologicznych przedstawia tabela 3 .

\section{Dyskusja}

Przejście zakażenia do wnętrza oczodołu jest najczęstszym powikłaniem zapalenia zatok przynosowych obserwowanych w każdej grupie wiekowej. Przede wszystkim dotyczą one dzieci do 7 roku życia [2]. Czynniki sprzyjające powstaniu powikłań w przebiegu zapalenia zatok to: niewłaściwy wybór antybiotyku, podawanie go w zbyt małych dawkach, narastająca antybiotykooporność patogenów, nawracające infekcje górnych dróg oddechowych. Znacznie rzadziej przyczyną zakażenia tkanek oczodołu mogą być czyraki skóry twarzy, zwłaszcza zlokalizowane na wardze górnej lub w przedsionku nosa $[3,4]$. W naszym materiale przeważająca większość chorych hospitalizowana była z powodu powikłań oczodołowych w przebiegu zapalenia zatok (22 chorych). U 5 chorych zapalenie tkanek oczodołu było spowodowane czyrakami w obrębie twarzoczaszki, u 2 chorych czynnikiem sprawczym był przebyty uraz twarzoczaszki. Pierwotne guzy oczodołu są bardzo rzadkie. Na podstawie rejestru guzów American Cancer Society występowanie guzów oczodołu ocenia się na mniej niż 1 na 100 tys. osób, co stanowi około 1\% wszystkich obserwowanych nowotworów [17]. Wśród zmian nowotworowych oczodołu chłoniaki stanowią od $10 \%$ do $30 \%$.W naszym materiale było 5 chorych z podejrzeniem guza oczodołu. U 3 z nich rozpoznano przewlekły stan zapalny, u 2 chłoniaka złośliwego.

\section{Podsumowanie}

Choroby oczodołu stanowią heterogenną grupę schorzeń. Wśród osób leczonych w Klinice Otorynolaryngologii Klinicznego Szpitala Wojewódzkiego Nr 1w Rzeszowie w latach 2000-2013 z powodu schorzeń oczodołu najliczniejszą grupę stanowili chorzy z powikłaniami oczodołowymi w przebiegu zapaleń zatok - 62,8\%. Rzadziej leczeni byli chorzy z podejrzeniem guza oczodołu - 14,2\%. Pozostali chorzy (23\%) leczeni byli z powodu schorzeń oczodołu innych niż wyżej wymienione.

\section{Piśmiennictwo:}

1. Łukasik S. Patologia oczodołu. Cz. I. Wiad Lek,1993; 46(13-14): 540-46.

2. Goździk-Żołnierkiewicz T, Krzeski A. Powikłania zapaleń zatok przynosowych. W: Krzeski A, Gromek I, red. Zapalenia zatok przynosowych. Gdańsk: VIA MEDICA; 2008, s. 157-82.

3. Goździk-Żołnierkiewicz T. Powikłania zapalenia zatok przynosowych. W: Krzeski A, Janczewski G, red. Choroby nosa i zatok przynosowych. Warszawa: Sanmedia; 1998, s. 239-52.
4. Składzień J. Patologie oczodołu. W: Niemczyk K, Jurkiewicz D, Składzień J, Stankiewicz Cz, Szyfter W, red. Otorynolaryngologia kliniczna 2. Warszawa: Medipage; 2015, s. 615-32.

5. Kowalik S, Janicki W, Kulig J, Krzystolik Z. Chirurgia oczodołów. W: Kowalik S, red. Chirurgia twarzy. Stalowa Wola: Medop; 2005, s. 347-80. 
6. Karolczak-Kulesza M, Pecold K. Przydatność badania ultrasonograficznego w monitorowaniu progresji/regresji patologicznych zmian oczodołowych. Okulistyka, 2000; 12(Wydanie Specjalne): $45-46$.

7. Vogl TJ, Balzer J, Mack M, Steger W. Oczodół. W: Vogl TJ, Balzer J, Mack M, Steger W, red. Radiodiagnostyka głowy i szyi. Lublin: Czelej; 2001, s. 185-210.

8. Lewandowski P. Diagnostyka ultrasonograficzna w okulistyce. Terapia, 2000; 8(11 z. 2): 24-27.

9. Składzień J. Podział oczodołu pod kątem leczenia guzów pozagałkowych. Okulistyka, 2000; 12 (Wydanie Specjalne): 10-11.

10. Łukasik S. Patologia oczodołu - cz. II. Metody rozpoznawania schorzeń oczodołu. Wiad Lek, 1993; 46(13-14): 547-51.

11. Krzeski A, Galewicz-Zielińska A. Powikłania oczodołowe zapalenia zatok przynosowych. W: Janczewski G, red. Otorynolaryngologia praktyczna. Tom I. Gdańsk: Via Medica; 2005, s. $340-50$.

12. Składzień J. Wybrane aspekty diagnostyki guzów pierwotnych oczodołu. Terapia, 2000; 8 (9 z.1): 18-19.
13. Mombaerts I, Schlingemann RO, Goldschmeding R, Koornneef L. Idiopathic granulomatosus orbital inflamation. Ophtalmology, 1996; 103(12): 2135-41.

14. Namysłowski G, Ścierski W, Misiołek M, Urbaniec N, Szendzielorz J, Lange D. Rzadki przypadek pierwotnej izolowanej sarkoidozy oczodołu u 53-letniej kobiety. Otolaryng Pol, 2004; 58(6): 1157-60.

15. Zgólski O, Składzień J. Problemy diagnostyki różnicowej ziarniny w oczodole. Otolaryng Pol, 2002; 56(6): 683-86.

16. Składzień J, Olszewski E, Reroń E, Modrzejewski M, Tomik J, Paziewski E. Pierwotne nowotwory oczodołu u dzieci. Otolaryng Pol, 1996; 50(1): 32-36.

17. Pieńkowski P, Wieloch M, Golusiński W, Pazdrowski J, Łuczewski Ł. Guzy oczodołu w materiale Oddziału Chirurgii Głowy i Szyi i Onkologii Laryngologicznej Wielkopolskiego Centrum Onkologii w Poznaniu w latach 2007-2010. Otolaryng Pol, 2012; 66(1): 39-42. 